\title{
Effects of initial fattening age on carcass characteristics and meat quality in Simmental bulls imported from Austria to Turkey
}

\author{
H. Ustuner ${ }^{1 \#}$, H. Yalcintan ${ }^{2}$, A. Orman ${ }^{1}$, S. Ardicli ${ }^{3}$, B. Ekiz ${ }^{2}$, H. Gencoglu ${ }^{4} \&$ O. \\ Kandazoglu ${ }^{5}$ \\ ${ }^{1}$ Department of Animal Science, Faculty of Veterinary Medicine, Uludag University, Gorukle/Bursa, 16059, Turkey \\ 2 Department of Animal Breeding and Husbandry, Faculty of Veterinary Medicine, Istanbul University, Avcllar/lstanbul, \\ Turkey \\ ${ }^{3}$ Department of Genetics, Faculty of Veterinary Medicine, Uludag University, Gorukle/Bursa, 16059, Turkey \\ ${ }^{4}$ Department of Animal Nutrition and Nutritional Disease, Faculty of Veterinary Medicine, Uludag University, \\ Gorukle/Bursa, 16059, Turkey \\ ${ }^{5}$ Tabiat Agriculture Limited Company, Yenisehir/Bursa, Turkey.
}

(Received 28 December 2016; Accepted 7 February2017; First published online 16 February 2017)

\author{
Copyright resides with the authors in terms of the Creative Commons Attribution 4.0 South African License. \\ See: http://creativecommons.org/licenses/by/4.0/za \\ Condition of use: The user may copy, distribute, transmit and adapt the work, but must recognize the authors and the South \\ African Journal of Animal Science.
}

\begin{abstract}
The aim of this study was to determine the effects of initial fattening age on carcass and meat quality of Simmental bulls imported from Austria to Turkey. These animals were allocated to two initial ages of fattening groups, namely young $(n=74)$ and old group $(n=61)$ at 5.5 and 7.5 months old, respectively. After reaching the target final weights, the animals were slaughtered and the carcass characteristics, area and circumference of the longissimus thoracis et lumborum (LTL) muscle, marbling score, and meat quality, including cooking loss, water-holding capacity (WHC), shear force (WBSF), and colour parameters were evaluated in six animals per group. A comparison of hot and cold carcass weights and dressing percentages, LTL circumference, fat thickness values and marbling score indicated no significant differences between young and old groups. However, the LTL area was significantly affected by the initial age. There were no significant differences between groups in WHC, cooking loss, and WBSF values and meat colour parameters. The results of this study showed that the initial fattening age of bulls showed no significant effect on carcass and meat quality parameters, except the LTL area. The LTL area was significantly higher in young group than the old group. Further studies are needed to improve carcass and meat quality of imported Simmental bulls through modifying the initial fattening age.
\end{abstract}

Keywords: Age, beef, carcass quality, Simmental

\#Corresponding author: hustuner@uludag.edu.tr

\section{Introduction}

Beef is an important component of the human diet and a source of valuable nutrients such as proteins, essential fatty acids, fat soluble vitamins, and minerals (Williamson et al., 2005). Thus, beef cattle production occupies an important place in meeting the nutrient requirements of the population in sufficient quantities. Livestock and beef production have gradually declined in Turkey as a result of several factors such as reducing the number of livestock, obtaining meat from slaughtered dairy cows, and lower carcass weights. Yet population growth has led to increased demand for meat products (Demirbas \& Tosun, 2005; Kirmizibayrak et al., 2011). Because of this increased demand and the decrease in beef production in Turkey, the price of meat is rising. Because of high meat prices, Turkish ministries have allowed the import of animals to regulate supply and demand and, in return, the price of red meat. However, importing red meat could not prevent price increases in red meat $(23.6 \%$ price increase). On the contrary, it has caused a lower native domestic supply (Cevger \& Sakarya, 2002; TSI, 2016). The Simmental steer is the preferred import, as it could adapt easily to Turkish conditions, is resistant to diseases, and produces high-quality beef at minimum cost (Akosman et al., 2013).

Improving fattening performance, carcass characteristics, and meat quality traits are the objectives of most research in beef production. Meat quality can be described as 'the attractiveness' of meat to consumers (Warner et al, 2010). The visual appearance of intramuscular fat content, commonly called marbling, is the primary criterion for quality grading of beef in the United States and Canada (Dubeski et al., 
1997). Meat quality, which refers to compositional quality and palatability of meat, is also an important criterion that influences the consumer's decision to purchase beef (Sami et al., 2004). The major parameters that are considered in the assessment of meat quality are appearance, juiciness, and tenderness (Lawrie \& Ledward, 2006). Tenderness has been identified as the most important palatability attribute of meat and the primary determinant of meat quality (Huffman et al., 1996).

Many factors affect ruminant carcass and meat quality. They may be divided into two categories: endogenous factors that are linked directly with the animal (breed, age, sex) and exogenous factors (diet, weather, slaughtering procedures, etc.), also called 'environmental factors' (Cross et al., 1984; Dannenberger et al., 2006).

Carcass and meat quality of beef breeds have been measured and compared in numerous studies. These comparisons have concentrated on the effects of fattening, fattening or slaughter age on carcass and meat quality characteristics (Chambaz et al., 2003; Özlütürk et al., 2004; Ekiz et al., 2005; Ugarković et al., 2013; Modika et al., 2015). There is limited information about the effect of initial fattening age on carcass, meat quality, and marbling score of imported Simmental bulls in Turkish conditions. The present study was therefore intended to determine the effects of initial fattening age on carcass and meat quality of Simmental bulls.

\section{Materials and Methods}

All procedures conducted for this research were done according to worldwide ethical considerations to ensure maximum animal welfare. The research protocol was approved by the Ethics Committee of Uludag University (Approval Number 2012-05/04).

The present study was carried out with Simmental bulls $(n=135)$ in the same commercial farm (Tabiat Agriculture Farm). The cattle were transported from Austria to Tabiat Agricultural Farm/Yenisehir/Bursa $\left(40^{\circ} 15^{\prime} 28.04^{\prime \prime} \mathrm{N} 29^{\circ} 30^{\prime} 50.18^{\prime \prime} \mathrm{E}\right)$ in Turkey. The animals were taken to holding paddocks (approximately 60 animals per truck, $1.3-1.5 \mathrm{~m}^{2}$ space per animal) based on similar live weights $( \pm 50 \mathrm{~kg})$ from the same herd. The duration of total transport was approximately 32 hours with an additional 24-hour rest period. After reaching the farm, these animals were allocated to the two initial ages of fattening groups, namely Group 1 (young) at 5.5 months old $(n=74)$ and Group 2 (older) at 7.5 months old $(n=61)$. Both groups had been fattened in the same semi-open barn and feeding conditions in different pens (approximately 20 bulls in a paddock, $10 \mathrm{~m}^{2}$ per animal). The animals were adapted to rations for about two weeks. All animals were fed ad libitum with the same diet (Table 1). The bulls had ad libitum access to water during the whole fattening period. Initial bodyweights of the groups were similar (Table 2).

Table 1 Components of total mix ration

\begin{tabular}{lc}
\hline Ingredient & Concentration (\%) \\
\hline Corn silage & 28 \\
Wheat straw & 27 \\
Macaroni pellets & 12 \\
Corn bran & 11 \\
Corn gluten feed & 10.5 \\
Sunflower meal & 6.5 \\
Vitamin and minerals & 5 \\
\hline
\end{tabular}

The animals that reached the target slaughter weight (Table 2) at monthly weighings were transported to an abattoir and slaughtered according to standard handling procedures. After being kept for 12 hours in paddocks, deprived of feed, but with full access to water, pre-slaughter live weights were recorded. Carcasses were weighed and chilled for 24 hours at $5^{\circ} \mathrm{C}$ and weighed again. Carcass and meat quality characteristics were evaluated using six randomly selected animals per group.

Meat quality characteristics were evaluated in samples of LTL, which were taken from the region of the $9^{\text {th }}$ and $10^{\text {th }}$ ribs at 24 hours post mortem. Samples were stored in refrigerators at $4^{\circ} \mathrm{C}$ until the next analysis. The LTL area and fat thickness were measured by planimeter (Ushikata 380d III, X Plan, TokyoJapan). 
The level of marbling in the present study was evaluated by looking at the prevalence of fat droplets on the cross-section surface of LTL. Marbling scores were evaluated by comparing them with photographic templates according to USDA standards. Marbling scores were described from least to most as follows: practically devoid (1), traces (2), slight (3), small (4), modest (5), moderate (6), slightly abundant (7), moderately abundant (8), and abundant (9).

To assess meat quality characteristics, $9-\mathrm{cm}$ thick steaks $(3.5 \mathrm{~cm}$ for cooking loss and WarnerBratzler shear force, $3 \mathrm{~cm}$ for colour and 2.5 for WHC) were taken from the LTL. These samples were packaged in vacuum bags and then kept at $4{ }^{\circ} \mathrm{C}$ for seven days before testing.

The WHC (\%) was measured with the modified Grau and Hamm method described by Beriain et al. (2000). To determine cooking loss, meat samples were first weighed, and then cooked in a water bath at 80 ${ }^{\circ} \mathrm{C}$ for $45 \mathrm{~min}$, as described by Honikel (1998). Cooking loss (\%) was estimated by means of percentage weight loss of the cooked sample compared with initial sample weight. After the measurement of cooking loss, cooked samples were used to determine the shear force. The procedure described by Ekiz et al. (2012) was used to prepare samples for shear force analysis. Briefly, six sub-samples, cut parallel to the muscle fibres and with a cross-section of $1 \times 1 \mathrm{~cm}$, were removed from each cooked sample. An Instron Universal Testing Machine (Model 3343, Norwood, MA, USA) equipped with Warner-Bratzler shear force (WBSF) apparatus was used to determine shear force values. The crosshead speed was $150 \mathrm{~mm} / \mathrm{min}$ and the force applied to the meat was set to $50 \mathrm{~kg}$. An average of the values for four sub-samples was accepted as the WBSF value for that sample.

Meat colour was measured at 0 hours, 1 hour, 24 hours and 7 days after storage on the cut surface of $2.5-\mathrm{cm}$ thick samples from a fat-free area. During the storage period, samples were kept at $4{ }^{\circ} \mathrm{C}$ in a polystyrene tray wrapped with oxygen-permeable PVC film to allow blooming. Nine colour measurements were performed on each sample. The colour coordinate value was determined by calculating the average of those nine measurements. Colour was evaluated with the CIELAB colour space system. L* (lightness), $a^{*}$ (redness) and $b^{\star}$ (yellowness) values were obtained with a Minolta CR 400 colorimeter (Minolta Camera Co., Osaka, Japan), with an $8 \mathrm{~mm}$ aperture size, $2^{\circ}$ observation angle and the illuminant D65 as the light source.

The Shapiro-Wilk (SW) test was performed to evaluate the normality of the data. The parametric analysis for initial and final weights and age was carried out by the $T$ test. Data were expressed as means and standard errors. In addition, carcass and meat quality characteristics were compared by the MannWhitney $U$ test for the evaluation of non-parametric distribution in the mentioned traits. Data were expressed as median with minimum and maximum values. Differences were considered significant at a probability level of $P<0.05$ in all analyses. Statistical analyses were performed using SPSS software (SPSS 20.0).

\section{Results}

The mean initial and final ages and weights of young and old groups are presented in Table 2. Differences between groups in terms of initial and final ages were significant $(P<0.01)$. Initial and final weights of the young group were not statistically different from those of the old group $(P>0.05)$.

Table 2 Means and standard errors of live weights, initial and final age of experimental groups

\begin{tabular}{|c|c|c|c|c|c|}
\hline \multirow{2}{*}{ Parameters } & \multicolumn{2}{|c|}{ Young Group $(n=74)$} & \multicolumn{2}{|c|}{ Old Group $(n=61)$} & \multirow{2}{*}{ Significance } \\
\hline & Mean & SE & Mean & SE & \\
\hline Initial weight (kg) & 220.75 & 8.67 & 222.75 & 8.84 & NS \\
\hline Final weight $(\mathrm{kg})$ & 615.83 & 7.16 & 615.58 & 3.92 & NS \\
\hline Initial age (day) & $167.58^{\mathrm{a}}$ & 5.45 & $224.26^{\mathrm{b}}$ & 6.37 & $* *$ \\
\hline Final age (day) & $433.33^{\mathrm{a}}$ & 4.59 & $490.00^{b}$ & 8.65 & $\star \star$ \\
\hline
\end{tabular}

Descriptive statistics of carcass characteristics for young and old groups are given in Table 3 . There were no significant differences between young and old groups regarding to the weights of hot and cold carcass $(\mathrm{kg})$, hot and cold dressing percentages (\%), LTL circumference $(\mathrm{cm})$, fat thickness $(\mathrm{mm})$ values, and marbling score. However, the LTL area $\left(\mathrm{cm}^{2}\right)$ was significantly affected by the initial age $(P<0.05)$. 
Table 3 Descriptive statistics of carcass characteristics of experimental groups

\begin{tabular}{|c|c|c|c|c|c|c|c|}
\hline \multirow{2}{*}{ Parameters } & \multicolumn{3}{|c|}{ Young Group $(n=74)$} & \multicolumn{3}{|c|}{ Old Group $(n=61)$} & \multirow[b]{2}{*}{ Significance } \\
\hline & Median & $\operatorname{Max}$ & Min & Median & $\operatorname{Max}$ & Min & \\
\hline Hot carcass weight $(\mathrm{kg})$ & 344.50 & 353.00 & 334.00 & 337.50 & 352.00 & 330.00 & NS \\
\hline Cold carcass weight (kg) & 338.75 & 347.50 & 329.00 & 332.50 & 346.50 & 324.50 & NS \\
\hline Hot dressing percentage (\%) & 56.50 & 57.00 & 54.00 & 55.50 & 57.00 & 53.00 & NS \\
\hline Cold dressing percentage (\%) & 55.38 & 56.05 & 53.02 & 54.67 & 55.89 & 51.92 & NS \\
\hline LTL area $\left(\mathrm{cm}^{2}\right)$ & $124.43^{\mathrm{a}}$ & 146.40 & 109.73 & $110.69^{b}$ & 114.27 & 85.35 & * \\
\hline LTL circumference $(\mathrm{cm})$ & 54.35 & 59.74 & 44.98 & 47.23 & 51.80 & 44.58 & NS \\
\hline Fat thickness (mm) & 0.36 & 0.45 & 0.24 & 0.36 & 0.87 & 0.22 & NS \\
\hline Marbling score & 2.00 & 1.00 & 2.00 & 2.00 & 3.00 & 2.00 & NS \\
\hline
\end{tabular}

There was no significant difference between young and older groups in terms of WHC, cooking loss and WBSF value (Table 4).

Table 4 Descriptive statistics of cooking loss, water holding capacity and Warner-Bratzler shear force values of longissimus thoracis et lumborum

\begin{tabular}{|c|c|c|c|c|c|c|c|}
\hline \multirow[b]{2}{*}{ Parameters } & \multicolumn{3}{|c|}{ Young group $(n=74)$} & \multicolumn{3}{|c|}{ Old group $(n=61)$} & \multirow[b]{2}{*}{ Significance } \\
\hline & Median & Max & Min & Median & Max & Min & \\
\hline CL (\%) & 31.57 & 33.55 & 20.18 & 33.88 & 35.31 & 29.42 & NS \\
\hline WHC (\%) & 8.01 & 9.42 & 6.15 & 9.52 & 12.00 & 6.41 & NS \\
\hline WBSF (kg) & 7.53 & 10.76 & 4.17 & 7.13 & 9.60 & 5.29 & NS \\
\hline
\end{tabular}

\footnotetext{
${ }^{\mathrm{CL}}$ Cooking loss; ${ }^{\mathrm{WHC}}$ Water holding capacity; ${ }^{\mathrm{WBSF}}$ Warner-Bratzler shear force

NS Not significant $(P>0.05)$
}

Descriptive statistics of meat colour characteristics of LTL are presented in Table 5. No differences were observed in terms of meat lightness $\left(L^{*}\right)$, redness $\left(a^{\star}\right)$ and yellowness $\left(b^{\star}\right)$ values for the two groups at 0 hours, 1 hour, 24 hours and 7 days after cutting $(P>0.05)$.

\section{Discussion}

Optimum slaughter age to achieve maximum net return and improved meat quality may differ depending on breed, castration age, gender, nutrition, and genetics, along with economic factors such as feed costs and carcass prices (Pyatt et al., 2005; Marti et al., 2013). Hence, an adequate evaluation of fattening performance in different cattle breeds may be a crucial point for beef production. Accordingly, in the current study, the effects of initial weight on carcass and meat quality traits were evaluated.

Carcass characteristics of beef cattle vary due to the genetic background, age and sex of the animal, and nutritional and environmental effects (Cross et al., 1984; Dannenberger et al., 2006). The results for the carcass weight $(\mathrm{kg})$ and dressing percentage (\%) were in accordance with the results reported by Chambaz et al. (2003), Sochor et al. (2005) and Schmutz et al. (2014) for Simmental bulls.

Litwińczuk et al. (2006) reported that dressing percentage rose with increasing slaughter weights of bulls. In the current study, there was no significant difference between groups in terms of hot and cold dressing percentage, probably because of similar slaughter weights in young and old groups.

The LTL area increases in parallel with slaughtering at a higher age (Sami et al., 2004). In contrast to Sami et al. (2004), the LTL area of the young group was higher $(P<0.05)$ than the old group, but the 
difference between groups in terms of LTL circumference was not significant $(P>0.05)$ in the current study. Crouse et al. (1986) noted that increased slaughter weight causes an increase in the LTL area. The existence of contrary results revealed in the present study might be caused by the genetic background of the animals. Thus, carcass traits, such as the LTL area, are under the control of the polygenic inheritance (Warner et al., 2010). However, more studies should be carried out to confirm the present results in larger Simmental populations. The LTL area values obtained in the study were similar with those reported by Arevalo-Turrubiarte et al. (2012), but higher than Sami et al. (2004) and Ozluturk et al. (2004).

Table 5 Descriptive statistics of meat colour characteristics of longissimus thoracis et lumborum muscles

\begin{tabular}{|c|c|c|c|c|c|c|c|}
\hline \multirow[b]{2}{*}{ Parameters } & \multicolumn{3}{|c|}{ Young group $(n=74)$} & \multicolumn{3}{|c|}{ Old group $(n=61)$} & \multirow[b]{2}{*}{ Significance } \\
\hline & Median & Max & Min & Median & Max & Min & \\
\hline \multicolumn{8}{|c|}{ Colour parameters at 0 hours } \\
\hline$\left(L^{*}\right)^{0 h}$ & 35.28 & 38.31 & 30.28 & 33.23 & 36.14 & 30.58 & NS \\
\hline$\left(a^{*}\right)^{0 h}$ & 15.47 & 19.99 & 13.78 & 16.57 & 18.81 & 15.53 & NS \\
\hline$\left(b^{\star}\right)^{0 h}$ & -0.46 & 1.54 & -2.46 & -0.98 & 0.59 & -1.84 & NS \\
\hline \multicolumn{8}{|c|}{ Colour parameters at 1 hour } \\
\hline$\left(L^{*}\right)^{1 \mathrm{~h}}$ & 35.80 & 39.56 & 30.84 & 34.15 & 36.33 & 31.32 & NS \\
\hline$\left(a^{*}\right)^{1 \mathrm{~h}}$ & 18.66 & 23.76 & 16.09 & 20.30 & 23.75 & 17.78 & NS \\
\hline$\left(b^{\star}\right)^{1 \mathrm{~h}}$ & 4.09 & 7.03 & 0.58 & 3.76 & 5.66 & 2.74 & NS \\
\hline \multicolumn{8}{|c|}{ Colour parameters at 24 hours } \\
\hline$\left(L^{\star}\right)^{24 h}$ & 37.01 & 42.41 & 33.09 & 36.29 & 39.39 & 32.91 & NS \\
\hline$\left(a^{\star}\right)^{24 h}$ & 22.29 & 24.87 & 17.05 & 22.96 & 27.14 & 21.32 & NS \\
\hline$\left(b^{\star}\right)^{24 h}$ & 6.64 & 8.78 & 3.41 & 6.70 & 8.12 & 5.03 & NS \\
\hline \multicolumn{8}{|c|}{ Colour parameters at 7 days } \\
\hline$\left(L^{*}\right)^{7 d}$ & 34.31 & 39.87 & 27.70 & 33.61 & 35.72 & 28.44 & NS \\
\hline$\left(a^{*}\right)^{7 d}$ & 15.92 & 17.65 & 13.39 & 16.13 & 23.02 & 14.36 & NS \\
\hline$\left(b^{\star}\right)^{7 d}$ & 4.19 & 5.81 & 1.39 & 4.10 & 4.58 & 2.88 & NS \\
\hline
\end{tabular}

${ }^{\text {NS }}$ Not significant $(P>0.05) ; L^{*}$ (lightness), a* (redness), b* (yellowness): meat colour parameters

Fatness level and carcass composition of various species might differ because of carcass weight and slaughter age. As animals become older, the proportion of fat in their carcasses increases and the proportion of muscles and bones decreases (Crouse et al., 1986; Irshad et al., 2013). In contrast to these reports, subcutaneous fat thickness was similar in carcasses from both young and old groups in the current study. Ugarković et al. (2013) reported that slaughter age (14 months and 19 months) had no significant effect on thickness of subcutaneous fat. Fat thickness $(6.42 \mathrm{~mm})$ was measured in Simmental beef bulls slaughtered at 15 months of age in the study performed by Ozluturk et al. (2004) had higher values than that of the old group (16.3 month-4.60 mm) in the current study.

Jennings et al. (1978) reported that increases in marbling above modest (score 5) were associated with improvements in tenderness, while the opposite was true of marbling scores of slight (3) and below. In this study, marbling scores seemed to be low for both groups of Simmental bulls. Accordingly, increased shear force values were observed. The distribution of intra-muscular fat and connective tissue affects the tenderness and marbling (Oliveira et al., 2011). Therefore, the findings of the current study indicated that the marbling level obtained for both groups (about 2 traces) might have resulted in tough meat.

The WHC is defined as the ability of meat to retain water during the application of external forces, such as cutting, heating, grinding and pressing (Zhang et al., 2005). It can be influenced by various, factors such as post-mortem glycolysis, rate of carcass temperature (Oliveira et al., 2011), and carcass fatness level (Lawrie \& Ledward, 2006). Meat WHC increases with intramuscular fat content, probably because the fat loosens up the myofibril microstructure, which allows more water to be entrapped (Lawrie \& Ledward, 2006). The non-significant difference between young and old groups in the current study might be related to similar 
fatness levels (carcass fat thickness and marbling score) of the groups. The WHC values obtained in the present study were similar to those of values reported by Teke et al. (2014) for Simmental bulls.

High quality meat loses less water during cooking (Lawrie \& Ledward, 2006). No differences in cooking loss were found between the young and old groups, but the young group lost 3.3\% less water than the older group. The cooking loss values in this study were consistent with those reported by Sochor et al. (2005), Crouse et al. (1986), and Oliveira et al. (2011), but higher than those reported by Chambaz et al. (2003) and Schmutz et al. (2014). The variation in cooking loss from various reports could be attributed to the different durations and temperature of cooking and the type of muscle (Simela, 2005).

Oliveira et al. (2011) and Frylinck et al. (2015) indicated that beef from younger groups presents less tenderness owing to lower levels of intra-muscular fat and greater amounts of connective tissue. However, in the current study, the WBSF values of the young and old groups were similar, which might be attributed to similar fatness level in the two groups. Revilla \& Vivar-Quintana (2006) reported that WBSF values ranging between 2.67 and $7.31 \mathrm{~kg}$ for Limousin and Charolais young bulls and heifers were acceptable by consumers. Shear force values for young and old groups in the current study were similar to results reported by Revilla \& Vivar-Quintana (2006). Therefore, the meat of young and old groups might be considered to be within the acceptable range in terms of tenderness.

Meat colour is one of the most important factors that affect consumers' acceptance, purchasing decisions, and satisfaction of meat products (Muchenje et al., 2009). In this study, initial ages of the animals did not affect the lightness $\left(L^{*}\right)$, redness $\left(a^{*}\right)$ or yellowness $\left(b^{*}\right)$ values measured at 0 hours, 1 hour, 24 hours and 7 days after cutting $(P>0.05)$. The results of the current study were in agreement with the findings of Marenčić et al. (2012), who reported that slaughter age (13 to 14 months and 17 to 18 months) did not affect the $L^{*}, a^{*}$ and $b^{*}$ values at 24 hours after cutting in Simmental bulls. Consumers appear to prefer beef that is neither extremely pale nor dark, with a range of values between 34 and 40 being considered normal (Ender \& Augustini, 1998). L* values of young and old groups were consistent with this data up to 24 hours but slightly decreased after the seventh day. Pigment concentration of diet, slaughter weight, fatness level of carcass (Beriain et al., 2000) and level of pre-slaughter stress (Teke et al., 2014) might influence the meat colour characteristics. Hence, these factors might be reasons for the similar colour values of young and old groups in the current study.

\section{Conclusion}

This study focused on the effects of the initial fattening age on carcass and meat quality of Simmental bulls. The present results showed that although initial fattening age of Simmental bulls showed no significant effect on most of the carcass and meat quality parameters, the LTL area of the young group was significantly higher than the old group. Further studies are needed to improve the carcass and meat quality of imported Simmental bulls, which are well adapted to conditions in Turkey, through modifying the initial fattening age or diet.

\section{Acknowledgments}

This work was supported by Uludag University Scientific Research Projects Unit (BAP) (Grant No: OUAP-V 2013/15). The authors gratefully thank Tabiat Agriculture Farm (Bursa) and Prof. Dr. Hasan Baspınar for their assistance.

\section{Authors' Contributions}

$\mathrm{HU}$ conducted the research and was responsible for drafting and submitting the manuscript. HY, SA, BE critically analysed and interpreted results and assisted in the revision of the original and revised manuscripts. AO was responsible for statistical analyses and HG, together with OK, assisted in animal husbandry.

\section{Conflict of Interest Declaration}

There are no conflicts of interest.

\section{References}

Akosman, M., Lenger, Ö. \& Demirel, H., 2013. Morphological, stereological \& histometrical assessment of the testicular parameters between Holstein and Simmental Bulls. Int. J. Morphol. 31, 1076-1080.

Arevalo-Turrubiarte, M., Gonzalez-Davalos, L., Yabuta, A., Garza, J., Davalos, J., Mora, O. \& Shimada, A., 2012. Effect of 2, 4-thiazolidinedione on limousin cattle growth and on muscle and adipose tissue metabolism. PPAR Res. 2012, 1-8.

Beriain, M., Horcada, A., Purroy, A., Lizaso, G., Chasco, J. \& Mendizabal, J., 2000. Characteristics of Lacha and Rasa Aragonesa lambs slaughtered at three live weights. J. Anim Sci. 78, 3070-3077.

Cevger, Y. \& Sakarya, E., 2002. Meat prices and factors affecting them in Turkey. Turk. J. Vet. Anim. Sci. 30, 1-6.

Chambaz, A., Scheeder, M., Kreuzer, M. \& Dufey, P.A., 2003. Meat quality of Angus, Simmental, Charolais and Limousin steers compared at the same intramuscular fat content. Meat Sci. 63, 491-500.

Cross, H., Crouse, J. \& MacNeil, M., 1984. Influence of breed, sex, age and electrical stimulation on carcass and palatability traits of three bovine muscles. J. Anim Sci. 58, 1358-1365. 
Crouse, J.D., Calkins, C.R. \& Seideman, S.C., 1986. The effects of rate of change in body weight on tissue development and meat quality of youthful bulls. J. Anim. Sci. 63, 1824-1829.

Dannenberger, D., Nuernberg, K., Nuernberg, G. \& Ender, K., 2006. Carcass-and meat quality of pasture vs concentrate fed German Simmental and German Holstein bulls. Arch. Anim. Breed. 49, 315.

Demirbaş, N. \& Tosun, D., 2005. Türkiye'de tarımın sanayi ile entegrasyonu, ortaya çıkan sorunlar ve çözüm önerileri. ADÜ Ziraat Fak. Derg. 2, 27-34 (in Turkish).

Dubeski, P., Aalhus, J., Jones, S., Robertson, W. \& Dyck, R., 1997. Meat quality of heifers fattened to heavy weights to enhance marbling. Can. J. Anim Sci. 77, 635-643.

Ekiz, B., Ekiz, E. E., Kocak, O., Yalcintan, H. \& Yilmaz, A., 2012. Effect of pre-slaughter management regarding transportation and time in lairage on certain stress parameters, carcass and meat quality characteristics in Kivircik lambs. Meat Sci. 90, 967-976.Ender, K. \& Augustini, C., 1998. Qualität von Fleisch und Fleischwaren. Deutscher Fachverlag Frankfurt am Main, 165-203.

Ekiz, B., Kocak, O. \& Yilmaz, A., 2005. Certain fattening and slaughter characteristics of Holstein, Brown Swiss and Simmental young bulls in the southeastern Anatolian region of Turkey. Bulg. J. Agric. Sci. 11, 199-206.

Frylinck, L., O'Neil, A., du Toit, E., Strydom, P.E. \& Webb, E.C., 2015. The beef tenderness model. S. Afr. J. Anim. Sci. 45 (3), 234-248.

Honikel, K.O., 1998. Reference methods for the assessment of physical characteristics of meat. Meat Sci. 49, 447-457.

Huffman, K.L., Miller, M.F., Hoover, L.C., Wu, C.K., Brittin, H.C. \& Ramsey, C.B., 1996. Effect of beef tenderness on consumer satisfaction with steaks consumed in the home and restaurant. J. Anim. Sci. 74, 91-97.

Irshad, A., Kandeepan, G., Kumar, S., Ashish, K., Vishnuraj, M. \& Shukla, V., 2013. Factors influencing carcass composition of livestock: A review. J. Anim. Prod. Adv. 3, 177-186.

Jennings, T., Berry, B. \& Joseph, A., 1978. Influence of fat thickness, marbling and length of aging on beef palatability and shelf-life characteristics. J. Anim. Sci. 46, 658-665.

Kirmizibayrak, T., Önk, K., Ekiz, B., Yalçintan, H., Yilmaz, A., Yazici, K. \& Altinel, A., 2011. Efects of age and sex on meat quality of Turkish native geese raised under a free-range system. Kafkas Univ. Vet. Fak. Derg. 17, 817-823.

Lawrie, R. \& Ledward, D., 2006. Lawrie's meat science. Woodhead, Cambridge, England. 336 pp.

Litwińczuk, Z., Barlowska, J., Florek, M. \& Tabala, K., 2006. Slaughter value of heifers, cows and young bulls from commercial beef production in the central eastern region of Poland. Anim. Sci. Pap. Rep. 24, 187-194.

Marti, S., Realini, C.E., Bach, A., Perez-Juan, M. \& Devant, M., 2013. Effect of castration and slaughter age on performance, carcass, and meat quality traits of Holstein calves fed a high-concentrate diet. J. Anim Sci. 91, 1129-1140.

Marenčić, D., Ivanković, A., Pintić, V., Kelava, N. \& Jakopović, T., 2012. Effect of slaughter age on meat quality of Simmental bulls and heifers. In Proceedings. 47th Croatian and 7th International Symposium on Agriculture. Opatija. Croatia, 13-17 February, vol. 718, pp. 721.

Muchenje, V., Dzama, K., Chimonyo, M., Strydom, P., Hugo, A. \& Raats, J., 2009. Some biochemical aspects pertaining to beef eating quality and consumer health: A review. Food Chem. 112, 279-289.

Modika, K.Y., Frylinck, L., Moloto, K.W., Strydom, P.E., Heinze, P.H. \& Webb, E.C., 2015. Visual evaluation of beef tenderness by using surface structural observations and its relationship to meat colour. S. Afr. J. Anim. Sci.45 (3), 255-262.

Oliveira, I.M.D., Paulino, P.V.R., Marcondes, M.I., Valadares Filho, S.D.C., Cavali, J., Prados, L.F., Duarte, M.D.S. \& Detmann, E., 2011. Beef quality traits of Nellore, F1 Simmental $\times$ Nellore and F1 Angus $\times$ Nellore steers fed at the maintenance level or ad libitum with two concentrate levels in the diet. Rev. Bras. Zootecn. 40, 2894-2902.

Özlütürk, A., Tüzemen, N., Yanar, M., Esenbuga, N. \& Dursun, E., 2004. Fattening performance, carcass traits and meat quality characteristics of calves sired by Charolais, Simmental and Eastern Anatolian Red sires mated to Eastern Anatolian Red dams. Meat Sci. 67, 463-470.

Pyatt, N.A., Berger, L.L., Faulkner, D.B., Walker, P.M. \& Rodriguez-Zas, S.L., 2005. Factors affecting carcass values and profitability in early-weaned Simmental steers: II. Days on feed endpoints and sorting strategies. J. Anim. Sci. 83, 2926-2937.

Revilla, I. \& Vivar-Quintana, A., 2006. Effect of breed and ageing time on meat quality and sensory attributes of veal calves of the Ternera de Aliste quality label. Meat Sci. 73, 189-195.

Sami, A., Augustini, C. \& Schwarz, F., 2004. Effects of feeding intensity and time on feed on performance, carcass characteristics and meat quality of Simmental bulls. Meat Sci. 67, 195-201.

Schmutz, M., Weindl, P., Carrasco, S., Bellof, G. \& Schmidt, E., 2014. The effects of breed, grazing system and concentrate supplementation on the fatty acid profile of the musculus longissimus dorsi and the kidney fat of steers. Arch. Tierz. 57, 1-16.

Simela, L., 2005. Meat characteristics and acceptability of chevon from South African indigenous goats (PhD thesis), Faculty of Natural \& Agricultural Sciences, University of Pretoria, South Africa.

Sochor, J., Simeonovová, J., Šubrt, J. \& Buchar, J., 2005. Effect of selected fattening performance and carcass value traits on textural properties of beef. Czech J. Anim. Sci. 50, 81-88.

Teke, B., Akdag, F., Ekiz, B. \& Ugurlu, M., 2014. Effects of different lairage times after long distance transportation on carcass and meat quality characteristics of Hungarian Simmental bulls. Meat Sci. 96, 224-229.

Turkish Statistical Institute (TSI), 2016. Annual Statistics, 51, April 21, Ankara.

Ugarković, N.K., Ivanković, A. \& Konjačić, M., 2013. Effect of breed and age on beef carcass quality, fatness and fatty acid composition. Arch. Tierz. 97, 958-970.

Warner, R.D., Greenwood, P.L., Pethick, D.W. \& Ferguson, D.M., 2010. Genetic and environmental effects on meat quality. Meat Sci. 86 (1), 171-183. 
Williamson, C., Foster, R., Stanner, S. \& Buttriss, J., 2005. Red meat in the diet. Nutr. Bull. 30, 323-355.

Zhang, S., Farouk, M., Young, O., Wieliczko, K. \& Podmore, C., 2005. Functional stability of frozen normal and high $\mathrm{pH}$ beef. Meat Sci. 69, 765-772. 